\title{
Three Cases of Nasal Chondromesenchymal Hamartoma Occurred in Sinonasal Tract
}

\author{
Yeonjoo Choi ${ }^{1}$, Yong Ju Jang ${ }^{1}$, Kyung-Ja Cho ${ }^{2}$, and Yoo-Sam Chung ${ }^{1} \mathbb{D}$ \\ 'Departments of Otorhinolaryngology-Head and Neck Surgery, ${ }^{2}$ Pathology, Asan Medical Center, College of Medicine, \\ University of Ulsan, Seoul, Korea
}

비강내에 발생한 연골간엽성 과오종 3예

최연주 ${ }^{1} \cdot$ 장용주 $^{1} \cdot$ 조경자 $^{2} \cdot$ 정유삼 $^{1}$

울산대학교 의과대학 서울아산병원 이비인후과학교실, ${ }^{1}$ 병리학교실 ${ }^{2}$

\author{
Received November 24, 2018 \\ Revised February 4, 2019 \\ Accepted February 11, 2019 \\ Address for correspondence \\ Yoo-Sam Chung, MD, PhD \\ Department of \\ Otorhinolaryngology- \\ Head and Neck Surgery, \\ Asan Medical Center, \\ College of Medicine, \\ University of Ulsan, \\ 88 Olympic-ro 43-gil, Songpa-gu, \\ Seoul 05505, Korea \\ Tel $+82-2-3010-3716$ \\ Fax $+82-2-489-2773$ \\ E-mail yschung@amc.seoul.kr
}

\begin{abstract}
Nasal chondromesenchymal hamartoma (NCMH) is a rare benign tumor of the sinonasal tract. Most NCMH has a benign nature and can be cured by complete resection. Only a few $\mathrm{NCMH}$ cases have been reported worldwide due to its rarity. Here, we report three cases of successfully treated $\mathrm{NCMH}$, of which one case was diagnosed during preliminary ultrasound. All three cases were consistent with the benign symptoms of NCMH. Tumor in all of the cases were successfully treated through an endoscopic approach surgery and no evidence of aggressive recurrence was reported. Korean J Otorhinolaryngol-Head Neck Surg 2019;62(11):651-6
\end{abstract}

Key Words Endoscopy · Nasal chondromesenchymal hamartoma · Nose neoplasms · Prenatal diagnosis.

\section{서 론}

비강내 연골간엽성 과오종(nasal chondromesenchymal hamartoma, $\mathrm{NCMH}$ )은 비강 및 부비동 내에 발생하는 드문 양성 질환이다. 대부분의 비강내 연골간엽성 과오종은 양성 경과를 보이며, 완전 절제를 통해 치유가 가능하다. 하지만 드물게 파괴적이며 공격적인 성향을 보이는 경우가 있어 때 때로 악성 종양으로 오인되는 경우도 보고되고 있다. 또한, 비강내 연골간엽성 과오종의 더딘 성장으로 인하여 임상에 서 늦은 발견이 문제가 되는 경우도 있다. 대부분의 비강내 연골간엽성 과오종은 신생아 혹은 1 세 미만의 영유아에서 발

This is an Open Access article distributed under the terms of the Creative Common Attribution Non-Commercial License (https://creativecommons.org/licenses/by-nc/4.0) which permits unrestricted non-commercial use, distribution, and reproduction in any medium, provided the original work is properly cited.
생한다. ${ }^{1)}$ 비강내 연골간엽성 과오종으로 인한 증상은 종양의 위치에 따라 다양하며, 종양이 주변 구조물들을 압박하거나 재형성(remodeling) 시킴으로써 발생한다. 비 폐색, 시야 장 애, 안면통 및 치통 등과 같은 증상들이 다양하게 나타날 수 있다. 전 세계적으로 57 증례의 비강내 연골간엽성 과오종이 보고 되었으며, ${ }^{2)}$ 국내에서는 3 증례가 보고 되었다. ${ }^{3-5)}$

저자들은 본원에서 진단 및 치료한 3예의 비강내 연골간엽 성 과오종에 대해 보고하고자 하며, 이중 1 예는 현재까지 국내 외 보고된 바가 없는 산전 초음파를 통하여 진단된 증례이다.

\section{증 례}

\section{증례 1}

생후 1 일 된 남아가 우측 비강내 종물을 주소로 본과에 
의뢰되었다. 종물은 환아모가 임신 28 주째 시행한 산전 초음 파를 통하여 확인되었다. 종물은 초음파상으로 $3 \times 2.5 \times 2.5$ $\mathrm{cm}$ 크기의 경계가 명확한 낭종성 종괴의 형태로, 좌측 비강 내에 위치하면서 좌측 안구 외벽을 압박하는 양상으로 확인 되었다(Fig. 1).

환아는 정상 만기 질식분만을 통해 태어났다. 환아는 경구

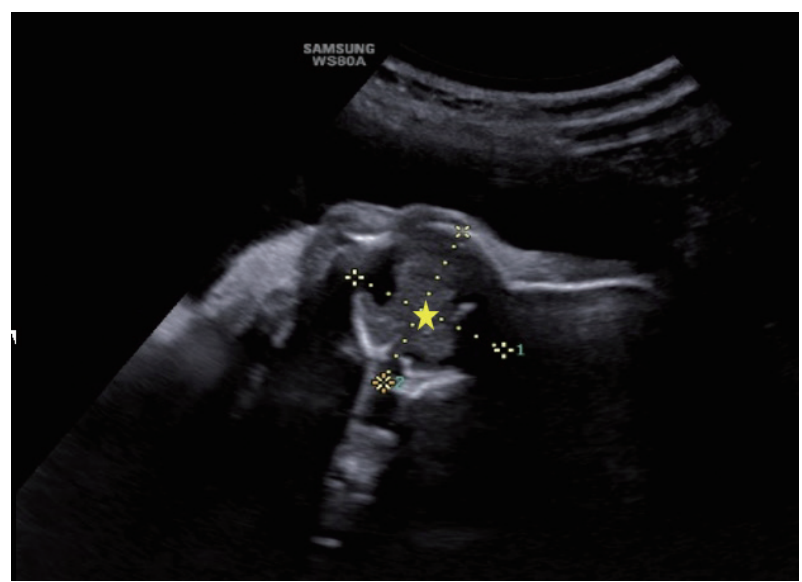

Fig. 1. Prepartum ultrasonography findings. $3.0 \times 2.5 \times 2.5 \mathrm{~cm}$ well defined septated cystic mass (star) extending to left orbit with contour deformity of left eyeball which is combined nasal septal deviation to right.
식이 때마다 산소포화도 저하 현상을 보였으며, 우측 눈을 완전하게 뜨지 못하였다. 내시경적 검사를 통하여 우측 비강 내 종물을 확인할 수 있었으며, 그 외의 신체검사 및 실험실 검사상 특이 소견은 확인되지 않았다.

출생 이후, 종물의 특징을 알아보기 위하여 컴퓨터단층촬 영(CT)과 자기공명영상법(MRI) 검사가 시행되었다. 부비강 컴퓨터단층촬영[paranasal sinus(PNS) CT]에서 우측 비강내 경계가 잘 지어지는 소엽상 종물이 확인되었고, 뚜렷한 두개 내 연결 소견은 확인되지 않았다(Fig. 2).

비인강 자기공명영상법(nasopharynx MRI)에서 내부 낭 종성 부분을 포함하는 불균일한 고형의 종물이 확인되었고 이는 주변 골 구조물의 변형을 유발하고 있었다. 이러한 발견 들을 통하여, 종물은 비강내 신경 교종(glioma) 혹은 기형종 (teratoma)과 같은 양성 종물의 가능성을 생각해 볼 수 있었 다(Fig. 3)

환아의 우측 비강내 종물로 인한 식이 시 산소포화도 저 하 현상을 해결하기 위하여 내비게이션 시스템(navigation system)을 통한 내시경적 부비동 수술이 시행되었다. 종물은 우측 비강내를 완전히 메우고 있었으며 중비도(middle meatus) 내에 위치하고 있었다. 종물은 두개 저(skull base) 혹은
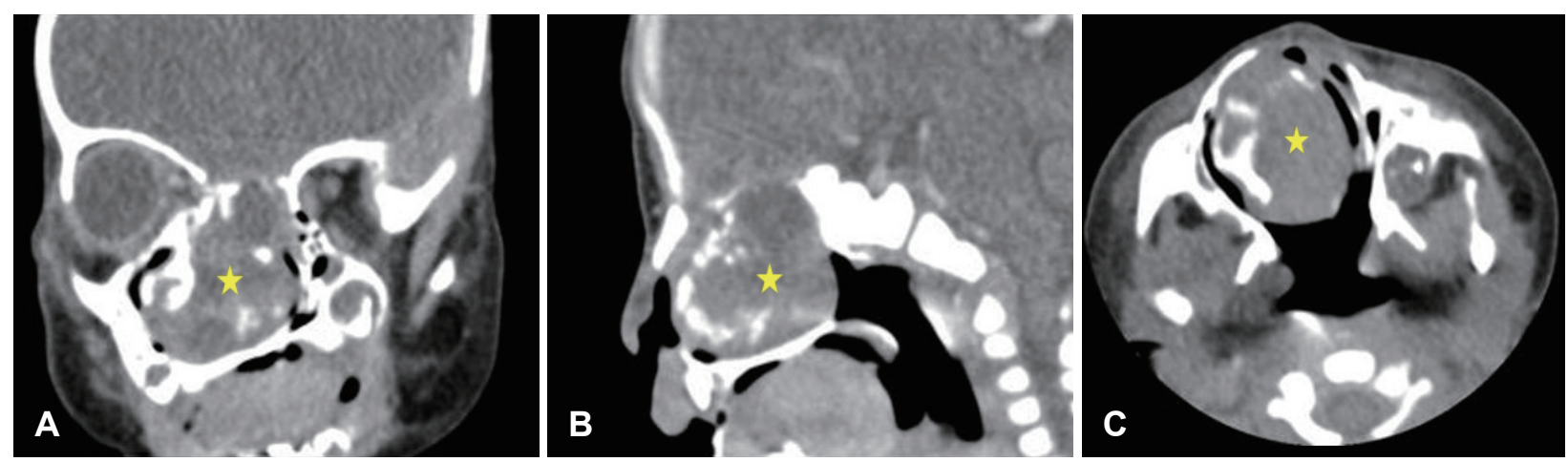

Fig. 2. Preoperative paranasal sinus CT findings. The well-defined lobulated expansile mass (stars) in right nasal cavity with irregular hyperdense component which has no obvious fat component. No definite intracranial communication, while widening of cribriform. Coronal view (A). Sagittal view (B). Axial view (C).
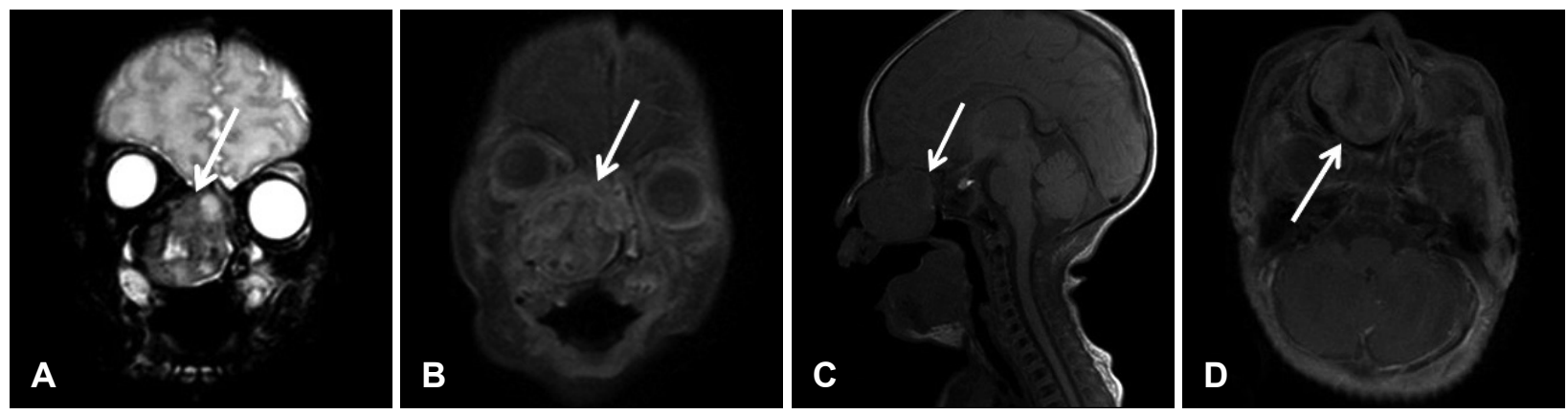

Fig. 3. Preoperative nasopharynx MR findings. The heterogenous solid mass (arrows) in right nasal cavity with internal some cystic portion causing adjacent bony remodeling. By left side bowing of nasal septum, lateral side was bowing by remodeling of medial wall of right maxillary sinus and right orbit. T2WI coronal view (A). T1WI Gd-enhanced coronal view (B). T1WI sagittal view (C). T1WI Gd-enhanced axial view (D). T1WI: T1-weighted image, T2WI: T2-weighted image. 

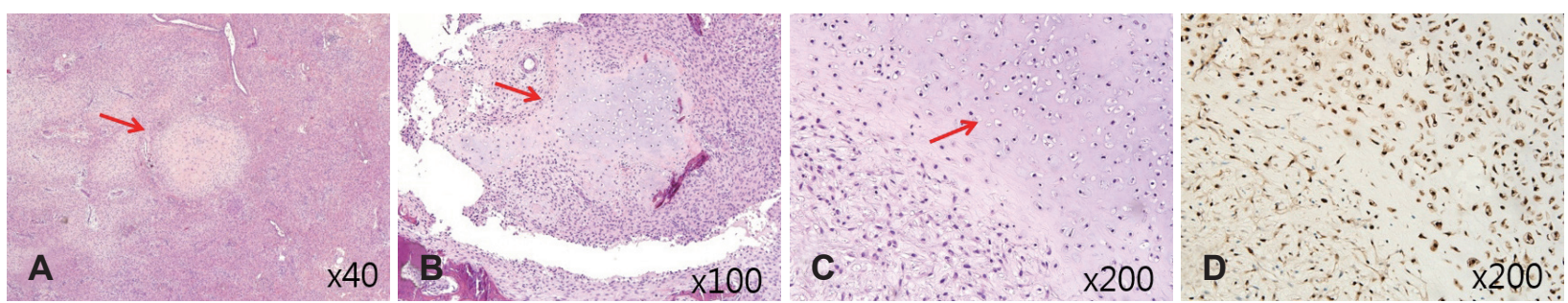

Fig. 4. Histologic features of final pathology. Cartilaginous component (arrows) containing bone formation lesion was identified in hematoxylin \& eosin stain (A-C). While positive in S-100 protein stain which represents chondroid tissue (D).
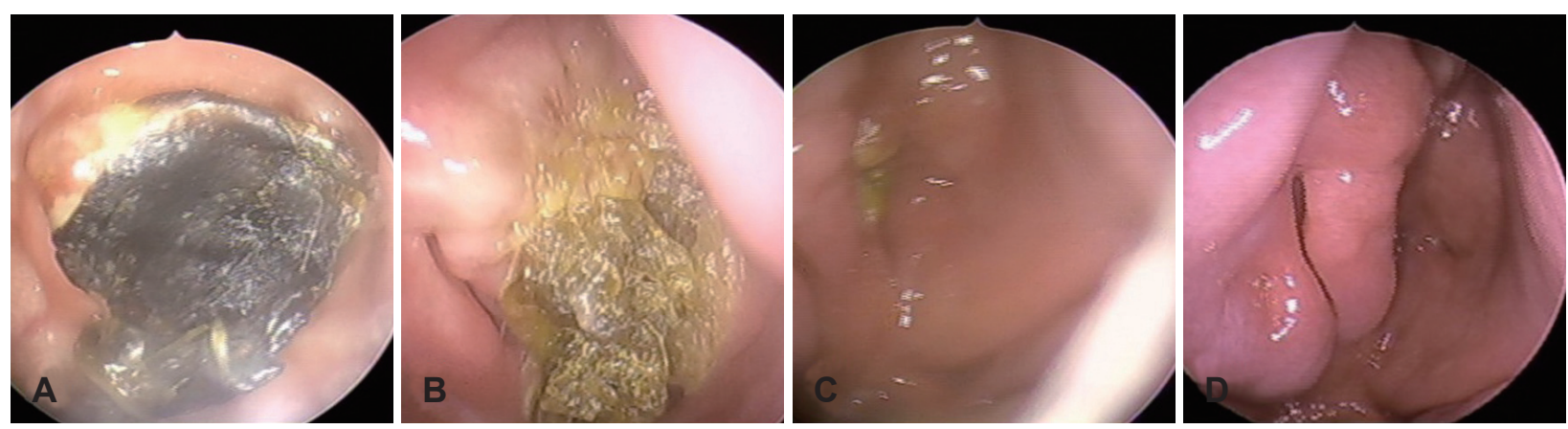

Fig. 5. Postoperative endoscopic findings. No evidence of recurrence was identified. Postoperative 10 days (A). Postoperative 3 month (B). Postoperative 6 month (C). Postoperative 1 year (D).

우측 중비갑개(middle turbinate)로부터 기원하는 것처럼 보 였으며, 두개 내 침범 소견은 확인되지 않았다. 종물 제거 후, 이전 종물로 인해 보이지 않던 비인두(nasopharynx)와 만곡 된 비중격(nasal septum)이 확인되었다. 시야로 확인되는 모 든 종물은 제거되었으며, 우측 사골동 후상방에 잔존 종물 로 의심되는 부위가 있었으나 저명하지 않았다. 뇌척수액 유 출은 확인되지 않았다. 최종 병리학적 판독에서 종물은 골 형성 부위를 포함하는 연골로 구성된 저 등급 연골간엽성 (low grade chondromesenchymal) 조직소견임을 확인하였 으며(Fig. 4A-C), 면역화학염색 결과상, S-100 단백질이 양 성 소견으로 확인되었다(Fig. $4 \mathrm{D})$. 상기 결과들을 통하여 연 골간엽성 과오종(chondromesenchymal hamartoma)이 진 단되었다. 환아는 수술 후 특별한 급성 합병증 없이 퇴원하 였으며, 이전 종물로 인하여 안구운동 장애와 우측 안검하 수(ptosis) 증상이 다소 남았다. 최종 조직검사 결과에 근거 하여 추가적인 치료 계획은 수립되지 않았다.

수술 직후 외래 내원 시에는 수술 부위로 가피(crust)가 형 성되어 있었으나 3 개월 간격으로 추적 관찰한 임상 경과에서 가피는 점차 줄어드는 양상을 보였다. 수술 후 1년까지 추적 관찰한 결과, 내시경적 검사상 재발 소견은 보이지 않았다 (Fig. 5). 내시경적 이상 소견이 보이지 않아 추가적인 영상학 적 검사는 시행하지 않았다. 안구운동 장애에 대하여 안과 협진을 시행하였고, 이전에 비해 안구장애가 다소 호전되었 음이 확인되었다.

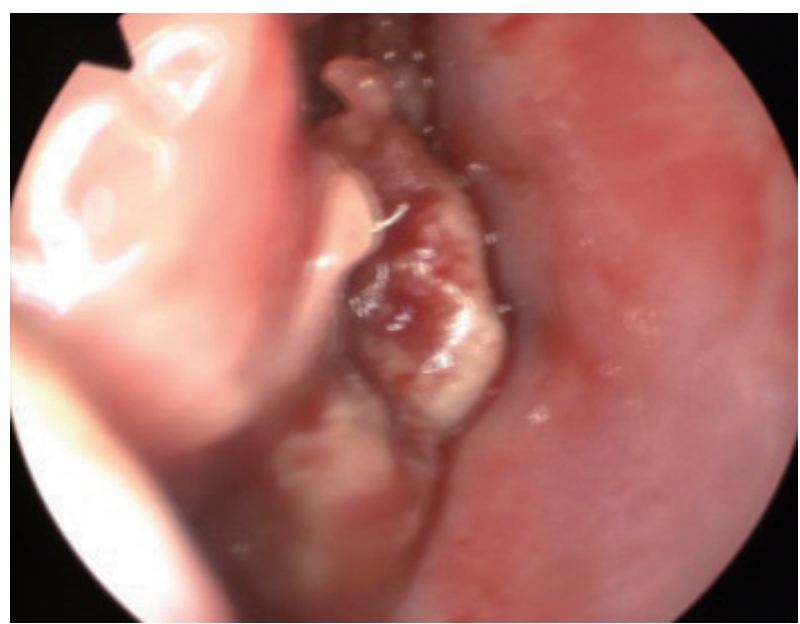

Fig. 6. Preoperative endoscopic findings. The tumor was occupied in right nasal cavity involving inferior turbinate and lateral side of middle turbinate.

\section{증례 2}

10 개월 된 남자 환아가 사시(strabismus) 및 안검하수 (ptosis) 소견으로 타원에서 의뢰되어 내원하였다. 환아는 우 측 비폐색 및 수양성 비루도 함께 호소하고 있었다. 안구의 움 직임은 없었으며, 시력 역시 거의 없었다. 내시경적 소견상 우 측 하비갑개(inferior turbinate)와 중비갑개(middle turbinate) 외측을 포함하여 비강 내부를 차지하고 있는 종물을 확인할 수 있었다(Fig. 6).

이전 타원에서 시행한 부비강 컴퓨터단층촬영(PNS CT) 

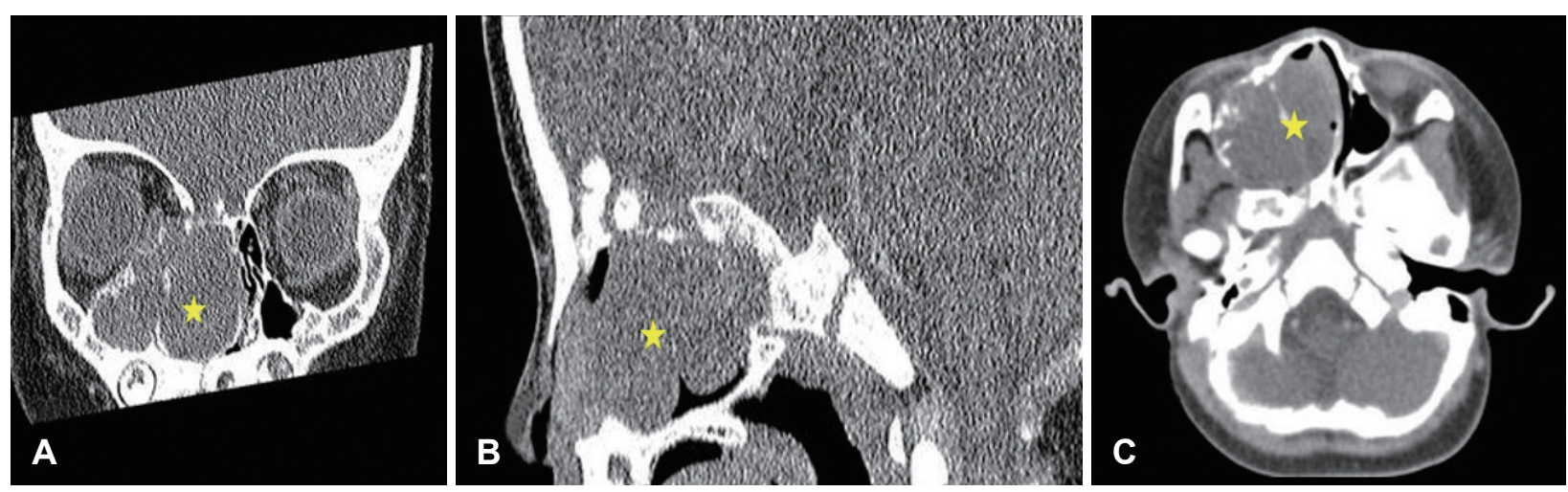

Fig. 7. Preoperative paranasal sinus CT findings. The expansile soft tissue mass (stars) involving right nasal cavity, maxillary sinus and ethmoidal sinus which had indentation to orbital floor while having no evidence of orbital extension and dural invasion. Coronal view (A). Sagittal view (B). Axial view (C).
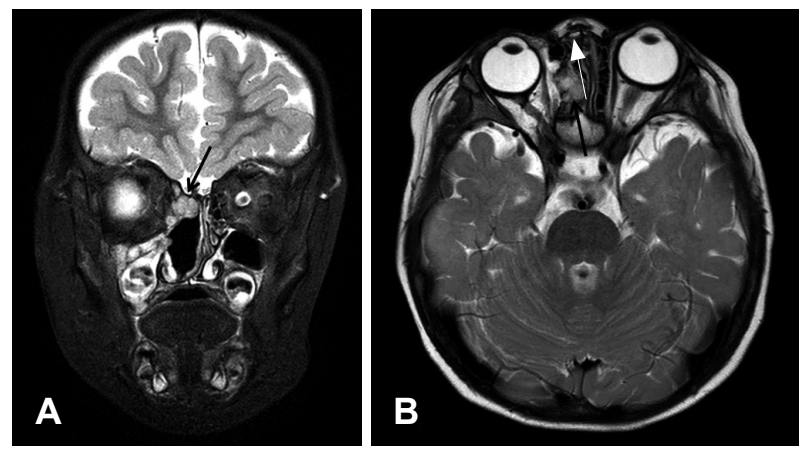

Fig. 8. Postoperative paranasal sinus MR findings. $1 \mathrm{~cm}$ sized T2 high signal intensity mass like lesion (arrows) in the ethmoidal sinus. T2WI coronal view (A). T2Wl axial view (B). T2Wl: T2-weighted image.

검사상 우측 비강, 상악동 및 사골동을 포함하고 있는 연부 조직으로 이루어진 종물이 확인되었다. 종물은 안구저(orbital floor)를 밀고 있는 양상이나 안구 혹은 경막(dura) 침 범 소견은 확인되지 않았다(Fig. 7). 내시경적 조직검사가 이 전 병원에서 시행되었고 연골간엽성 과오종(chondromesenchymal hamartoma)을 시사하는 저 등급 연골점액양섬유 종(low grade chondromyxoid) 조직이 확인되었다.

병변에 대하여 내비게이션 시스템(navigation system)을 통한 내시경적 부비동 수술이 시행되었으며, 상악동 근치술 (Caldwell-Luc operation)이 함께 시행되었다. 종물은 상악 동을 가득 채우고 있었으며, 정상 조직이 확인될 때까지 종 물을 모두 제거하였다. 하비갑개(inferior turbinate) 및 중비 갑개(middle turbinate)의 외측을 포함하는 비강내 종물 역 시 완전히 절제되었다.

최종 조직검사 결과, 종물은 이전 내시경적 조직검사 결과 와 동일하게 저 등급 연골점액양섬유종(low grade chondromyxoid)으로 확인되었고 이는 연골간엽성 과오종(chondromesenchymal hamartoma)을 시사하는 소견이었다. 면역화
학염색 결과, 평활근(smooth muscle)의 액틴(actin)과 S-100 단백질에 모두 양성 소견을 보였다.

환아는 경도의 안면 비대칭을 보였으나, 이 외에 특별한 합 병증 없이 퇴원하였다. 수술 3개월 뒤 컴퓨터단층촬영(CT), 6 개월 뒤 자기공명영상법(MRI) 촬영이 시행되었고, 재발을 포함한 특이소견은 확인되지 않았다. 수술 1년 뒤 시행한 자 기공명영상법(MRI) 검사에서 안와 및 경막 침범이 없는 우 측 사골동에 국한된 $1 \mathrm{~cm}$ 크기의 종물이 확인되었다(Fig. 8). 매년 종양 크기 변화를 알아보기 위하여 자기공명영상법 (MRI) 검사가 시행되었고 상기 검사상에서 종물은 여전히 관찰되나 수술 후 5년이 되는 시점까지 크기 변화는 없었다. 상기 결과에 기반하여 종물에 대하여 추가적인 치료는 시행 하지 않기로 하고, 매년 자기공명영상법(MRI)을 통하여 추 적 관찰을 하기로 하였다.

\section{증례 3}

12세 여아가 타원에서 우연히 발견된 좌측 비용종을 주소 로 본원에 내원하였다. 이전 특이 병력은 없었으며 신체 검진 상에서도 좌측 비용종을 제외하고 이상 소견은 확인되지 않 았다.

부비동개구연합 컴퓨터단층촬영(ostiomeatal unit CT)가 시 행되었고, 좌측 비강내 다수의 비용종이 확인되었다(Fig. 9).

병변에 대하여 좌측 내시경적 비용종 적출술을 시행하였 다. 환아는 수술 후 급성 합병증 없이 퇴원하였다.

최종 조직검사 결과, 비용종은 비강내 연골간엽성 과오종으 로 확인되었고, 추가적인 면역화학검사는 시행되지 않았다.

수술 후 6개월 뒤 외래에서 시행된 내시경적 소견상 재발 소견 확인되지 않았다. 연고지 병원에서 추적 관찰 원하여 본원 추적관찰은 종료되었다. 

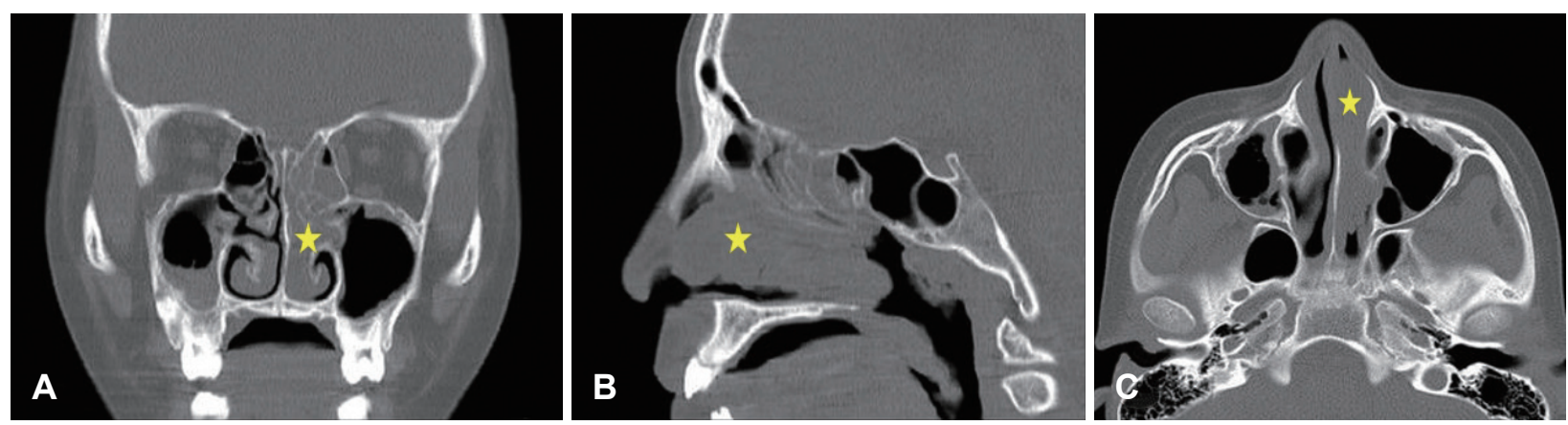

Fig. 9. Preoperative ostiomeatal unit CT findings. The multiple nasal polyps in left nasal cavity (stars). Coronal view (A). Sagittal view (B). Axial view (C).

\section{고 찰}

비강내 연골간엽성 과오종(NCMH)은 비강 및 부비동 내 에 발생하는 드문 양성 질환 중 하나이다. 때때로 공격적인 성향을 보일 때도 있어, 악성 종양으로 오인되는 경우도 있 다.) 대부분의 비강내 연골간엽성 과오종은 양성 경과를 보 이나, 2013년 Li 등긔 연구에서 비강내 연골간엽성 과오종 이 악성을 띄는 증례가 보고된 바 있다. 이는 현재까지 유일 한 악성 변화를 보이는 증례이다.

비강내 연골간엽성 과오종은 1998 년 McDermott 드일에 의 하여 처음 보고되었다. 그들은 비강내에 발생한 연골간엽성 과오종이 다른 종양과 구별되는 임상적-병리학적 특징들에 대하여 서술하였다. 비강내 연골간엽성 과오종으로 인한 임 상 증상은 종양이 비강내 어느 위치에 발생하느냐에 따라 다 양하게 나타난다. 비 폐색, 시야 장애, 안면통 및 치통 등과 같은 증상들이 나타날 수 있다. McDermott 등른 7예의 비 강내 연골간엽성 과오종을 보고하였으며, 그중 6 예에 해당하 는 환자의 나이는 생후 3 개월 미만이었다. 또 다른 연구에서 도 비강내 연골간엽성 과오종이 어린 나이에 주로 발현하며, 대부분 1 세 미만의 유아에서 발생된다고 보고하고 있다.) 하 지만, 드물게 성인에서도 보고되며, 증례를 통하여 69세까지 발생한 것으로 확인된다. ${ }^{78)}$

비강 및 부비동 내에 발생하는 질환의 진단을 위하여 시행 되는 영상학적 검사는 종양의 성질 및 주변 구조물과의 관계 까지 포함하는 정보를 제공해줄 수 있다. 비강내 연골간엽성 과오종의 경우 컴퓨터단층촬영(CT) 영상에서 낭성 부분을 포함하는 불분명한 경계의 종양으로 보여질 수 있다. 자기공 명영상법(MRI) 역시 조직의 성분의 특징 및 주변 구조물의 침입 여부를 알아보는 데 도움을 줄 수 있다.' 하지만, 초기 에 영상 검사상으로 비강 및 부비동 내에서의 연골간엽성 과 오종을 진단하는 것은 어렵고 실수를 범하기 쉽다. ${ }^{6}$ 비강내 연골간엽성 과오종이 드물게 보고됨으로 인하여, 다른 질환
들로 오진되는 경우가 흔하다. 반전성 유두종(inverted papilloma), 동맥류뼈낭종(aneurysmal bone cyst), 화골성 섬유 종(ossifying fibroma), 비사골복합체 뇌낭류(nasoethmoidal encephalocele), 연골 육종(chondrosarcoma), 비강내 림프 종(nasal lymphoma), 비강내 신경 교종(nasal glioma), 횡문 근육종(rhabdomyosarcoma) 등이 연골간엽성 과오종과 감 별해야 할 질환이다. 최종 진단은 수술로부터 나온 검체의 조 직학적 결과로 확정 지어진다. 조직 병리학적으로 연골간엽 성 과오종은 유리질 연골(hyaline cartilage) 및 석회화(calcification)로 구성된 연골 조직과 방추상 세포(spindle cell) 및 점액성 기질(myxoid stroma)로 이루어진 간엽성(mesenchymal) 세포 조직으로 구성되어 있다. ${ }^{6}$ 면역화학검사는 기 질성(stromal)과 간엽성(mesenchymal)의 요소들을 알아볼 수 있는 방법으로 S-100 단백질 염색을 통하여 성숙한 연골 (mature cartilage)의 유무를 확인할 수 있으며, CD68 염색, 평활근(smooth muscle)의 액틴(actin) 염색을 통하여 방추 상 세포(spindle cell)의 유무를 알 수 있다. ${ }^{1)}$

비강내 연골간엽성 과오종의 병태생리는 여전히 논란이 있 으나, 현재까지 가장 잘 알려진 가설로는 유전적 소인에 의해 발생하는 것으로 알려져 있고, 이는 대부분의 증례가 어린 나 이에서 발생한다는 것으로 뒷받침된다. Stewart 등이과 Priest 등믄 은 비강내 연골간엽성 과오종과 소아에서 폐와 흥막에 발생하는 발생학적인 육종 중 하나인 흥막 및 폐 모세포종 (pleuropulmonary blastoma)의 유전적 특징에 대하여 연구 하였다. 연구에 따르면 비강내 연골간엽성 과오종과 흥막 및 폐 모세포종을 갖고 있는 8명의 환자 중 6명에서 DICER1 생 식세포 유전자 변형을, 그중 2명에서 체세포 변형이 확인되었 다. 하지만 이 연구의 경우 연구 대상자 수가 적어 모든 비강 내 연골간엽성 과오종 환자에서 모두 DICER1 변형을 보인 다고 결론 내리기에는 한계가 있어 DICER1 변형이 비강내 연골간엽성 과오종 환자에서 어떠한 의미가 있을지, DICER1 변형을 비강내 연골간엽성 과오종 환자에서 확대 적용할 수 
있을지에 대한 추가적인 연구가 필요하다.

비강내 연골간엽성 과오종의 치료는 완전 절제술이 그 기 본이 된다. 종양의 불완전한 절제는 재발의 위험도를 높인다. 대부분의 비강내 연골간엽성 과오종이 양성을 띄기 때문에, 대부분의 재발은 초기에 완전히 절제되지 않았을 경우에 생 길 가능성이 높다. ${ }^{6}$ 종양이 비강내에서 주변의 침범 없이 존 재할 경우에 완전 절제될 가능성이 높지만, 종양이 주변 구 조물을 침범하면서 두개 내까지 침범하고 있다면 완전 절제 는 어렵다. ${ }^{12)}$ 비내 내시경이 도입되기 이전에는 완전 절제를 위하여 비 외 접근법을 함께 시행하여야 했지만, 비내 내시경 이 도입된 1990년 이후부터는 내시경적 접근이 가능해졌다. 최근 비내 내시경의 발전으로, 내시경만으로도 비강 및 부비 강을 넘어서 존재하는 종양들까지도 절제를 하는 것이 가능 해졌다. ${ }^{13)}$ 한 연구에서는 두개 저 앞 부위까지 침범하고 있는 비강내 연골간엽성 과오종을 내시경적 접근으로 절제하였고, 이후 재발 없이 유지되고 있다고 보고하고 있다. ${ }^{14)}$

저자들이 경험한 비강내 연골간엽성 과오종 3예에서는 공 격적인 재발 소견은 관찰되지 않았으며, 모든 증례에서 수술 적 절제를 통하여 추시 기간 동안 성공적인 결과를 확인할 수 있었다. 이전에 보고된 증례들과 비교해 보았을 때, 모든 증례가 어린 나이에 발생하였다는 공통점을 가지고 있으며, 이는 연골간엽성 과오종의 발생에 있어 유전적 소인이 중요 한 역할을 할 수 있다는 가설을 뒷받침하는 결과라 할 수 있 겠다. 또한, 이 논문을 통해 보고된 3예의 증례 모두 추가적 인 외부 접근을 통한 반흔 형성 없이 내시경적으로 접근하였 다는 점과, 1 예에서는 산전 초음파를 통하여 연골간엽성 과 오종을 조기진단 하였다는 점이 이전 증례들과 다른 점이라 할 수 있겠다. 산전 초음파를 통하여 비강내 연골간엽성 과 오종을 진단한 것은, 현재까지 국내외 보고된 바가 없는 첫 증례이다. 빠른 진단으로 인하여 환아가 출생 직후 지연 없 이 수술적 치료를 받을 수 있었고, 이를 통하여 환아의 안구 증상 및 호흡 곤란 증상을 신속하게 교정할 수 있었다는 점 에서 이 증례가 가지는 의미가 있다.

결론적으로, 비강내 연골간엽성 과오종은 비강 및 부비강 내에 발생하는 매우 드문 질환 중 하나이며 감별진단이 중요 하다. 저자들이 보고한 비강내 연골간엽성 과오종 3예 모두 내시경적 절제술을 통하여 성공적으로 치료되었으며, 이후 공격적인 재발 소견은 보이지 않았다. 연골간엽성 과오종은 그 빈도는 높지 않으나, 어린 환아에서 비강내 종물이 확인될
경우 반드시 감별해야 하는 질환 중의 하나임을 염두에 두어 야 한다.

\section{ORCID}

Yoo-Sam Chung https://orcid.org/0000-0002-8866-5415

\section{REFERENCES}

1) McDermott MB, Ponder TB, Dehner LP. Nasal chondromesenchymal hamartoma: An upper respiratory tract analogue of the chest wall mesenchymal hamartoma. Am J Surg Pathol 1998;22(4):425-33.

2) Golbin DA, Ektova AP, Demin MO, Lasunin N, Cherekaev VA. Nasal chondromesenchymal hamartoma with skull base and orbital involvement: Case presentation. Cureus 2018;10(6):e2892.

3) Kim JE, Kim HJ, Kim JH, Ko YH, Chung SK. Nasal chondromesenchymal hamartoma: CT and MR imaging findings. Korean J Radiol 2009; 10(4):416-9.

4) Kang J, Hong YO, Ahn GH, Kim YM, Cha HJ, Choi HJ. Nasal chondromesenchymal hamartoma: A case report. Korean J Pathol 2007;41(4):258-62.

5) Chae HJ, Suk JH, Lee SK. Nasal chondromesenchymal hamartoma: A case report. Korean J Pathol 1999;33(3):225-7.

6) Mason KA, Navaratnam A, Theodorakopoulou E, Chokkalingam PG. Nasal chondromesenchymal hamartoma ( $\mathrm{NCMH})$ : A systematic review of the literature with a new case report. J Otolaryngol Head Neck Surg 2015;44:28.

7) Li Y, Yang QX, Tian XT, Li B, Li Z. Malignant transformation of nasal chondromesenchymal hamartoma in adult: A case report and review of the literature. Histol Histopathol 2013;28(3):337-44.

8) Ozolek JA, Carrau R, Barnes EL, Hunt JL. Nasal chondromesenchymal hamartoma in older children and adults: Series and immunohistochemical analysis. Arch Pathol Lab Med 2005;129(11):1444-50.

9) Yao-Lee A, Ryan M, Rajaram V. Nasal chondromesenchymal hamartoma: Correlation of typical MR, CT and pathological findings. Pediatr Radiol 2011;41(5):675-7.

10) Stewart DR, Messinger Y, Williams GM, Yang J, Field A, Schultz KA, et al. Nasal chondromesenchymal hamartomas arise secondary to germline and somatic mutations of DICER1 in the pleuropulmonary blastoma tumor predisposition disorder. Hum Genet 2014;133(11): 1443-50.

11) Priest JR, Williams GM, Mize WA, Dehner LP, McDermott MB. Nasal chondromesenchymal hamartoma in children with pleuropulmonary blastoma--A report from the International Pleuropulmonary Blastoma Registry registry. Int J Pediatr Otorhinolaryngol 2010;74 (11):1240-4.

12) Nakaya M, Yoshihara S, Yoshitomi A, Baba S. Endoscopic endonasal excision of nasal chondromesenchymal hamartoma with intracranial extension. Eur Ann Otorhinolaryngol Head Neck Dis 2017;134(6): 423-5.

13) Nakaya M, Kida W, Ito A, Yoshihara S, Fuchigami T. Endoscopic transoral and transmaxillary excision of the infratemporal fossa hemangioma. Auris Nasus Larynx 2015;42(3):258-62.

14) Eloy P, Trigaux H, Nassogne MC, Weynand B, Rombaux P. Nasal chondromesenchymal hamartoma: Case report. Int J Pediatr Otorhinolaryngol 2011;6(4):300-3. 